\title{
Cocoa Beans and Cocoa Derivatives from Cote-D'Ivoire: Investigating Ochratoxin A Level and Assessing Dietary Intake Adults
}

\author{
Adama Coulibaly ${ }^{1,2}$, Godi Henri Marius Biego ${ }^{2}$, Ardjouma Dembele ${ }^{1}$, \\ Kouassi Maxime Bohoussou ${ }^{2} \&$ Abba Toure ${ }^{3}$ \\ ${ }^{1}$ Central Laboratory of Agrochemistry and Ecotoxicology, Cote d'Ivoire \\ ${ }^{2}$ Laboratory of Biochemistry and Food Sciences, UFR Biosciences, Abidjan-Cocody University Houphouet \\ Boigny, Cote d'Ivoire \\ ${ }^{3}$ Environment and Health Department, Institute Pasteur, Cote d'Ivoire \\ Correspondence: Godi Henri Marius Biego, Laboratory of Biochemistry and Food Sciences, UFR Biosciences, \\ Abidjan-Cocody University Houphouet Boigny, Cote d'Ivoire. E-mail: biegoh3@yahoo.fr
}

Received: July 18, 2012 Accepted: September 21, 2012 Online Published: November 25, 2012

doi:10.5539/sar.v2n1p173

URL: http://dx.doi.org/10.5539/sar.v2n1p173

\begin{abstract}
The aim of this study was the determination of the level of ochratoxin A (OTA) in cocoa beans and derived products along with the estimation of the dietary intake in adults. Throughout harvesting seasons from 2005 to 2009 , as many as 1895 samples of cocoa beans were collected at ports and areas of cocoa production and thereafter analyzed. OTA concentrations were determined by HPLC according to the standards of the European Communities (CE 401/2006). OTA intakes were assessed using data obtained from the analysis and the estimated Ivorian adult daily consumptions of cocoa beans and chocolate. Average OTA levels depending on cocoa grades were as follows: $0.64 \pm 0.53 \mu \mathrm{g} / \mathrm{kg}$ for marketable beans, $1.90 \pm 1.87 \mu \mathrm{g} / \mathrm{kg}$ for non-marketable beans and $1.40 \pm 1.32 \mu \mathrm{g} / \mathrm{kg}$ for total beans). As regards the types of beans, OTA concentrations ranged from $0.19 \pm 0.16$ $\mu \mathrm{g} / \mathrm{kg}$ (shelled beans) to $1.90 \pm 1.87 \mu \mathrm{g} / \mathrm{kg}$ (unshelled beans). OTA levels in beans were below the maximum concentration of OTA allowed $(2 \mu \mathrm{g} / \mathrm{kg}$ of beans).

Besides, OTA concentrations obtained from chocolate were comprised between $0.048 \pm 0.040 \mu \mathrm{g} / \mathrm{kg}$ for sweet chocolate made from marketable shelled beans and $0.66 \pm 0.65 \mu \mathrm{g} / \mathrm{kg}$ for dark chocolate made from non-marketable unshelled beans.

Dietary intakes were respectively equal to $3.70 \pm 3.00 \mathrm{pg} / \mathrm{kg}$ body weight/day for the marketable shelled beans and $36.5 \pm 34.0 \mathrm{pg} / \mathrm{kg}$ body weight/day for the unshelled non-marketable beans. Those dietary intakes appeared to be by far lower than the Tolerable Daily Intake set by the Scientific Committee o Food $(5000 \mathrm{pg} / \mathrm{kg}$ body weight/day). However, in view of the toxicity of OTA, it is imperative to foster best practices of harvesting, pod breaking, drying and storage of the beans for the total elimination of OTA from Ivorian cocoa beans.
\end{abstract}

Keywords: intake of OTA, cocoa products, health risk

\section{Introduction}

Cocoa beans after post-harvest treatments are mainly exported to Europe and North America to be turned into liquor, butter and cocoa powder (Tafuri, et al., 2004; International Cocoa Organization [ICCO], 2007). Cocoa and various derivatives contamination with Ochratoxin A has been revealed by numerous studies (Miraglia \& Brera, 2002; Burdaspal \& Legarda, 2003; Bonvehi, 2004; Tafuri et al., 2004; Matsuoka, 2006; Christine, 2007; Dembele et al., 2007; Dembele et al., 2009).

Ochratoxin A, a mycotoxin produced by fungi Aspergillus and Penicillium, is endowed with nephrotoxic, teratogenic and immunosuppressive activities (Moré \& Galtier, 1974; Dwidedi \& Burns, 1984; Boorman et al., 1984; Castegnaro et al., 1998; Castegnaro, 1999). It has been classified as carcinogens 2B that is a possible human carcinogen by the International Agency for Research on Cancer (International Agency for Research on Cancer [IARC], 1993). OTA is deemed as one of the agents involved in the etiology of Balkan endemic nephropathy (Petrova-Bocharov et al., 1988), tumors of the urinary tract in Tunisia (Maaroufi et al., 1996) and Egypt (Waffa et al., 1998). The Superior Council for Public Hygiene of France (Conseil Supérieur de l'Hygiène Publique de France [CSHPF], 1999) and the Scientific Committee on Food (Scientific Committee on food [SCF], 
1998) established a tolerable daily intake (TDI) of $5 \mathrm{ng} / \mathrm{kg}$ body weight/day based upon data from "in vivo" experiments accounting for nephrotoxicity in rats. In addition, a significantly higher TDI $(14 \mathrm{ng} / \mathrm{kg}$ body weight/day) was established by the Joint FAO/WHO committee experts on food additives and contaminants from the results of studies corroborating nephrotoxicity effects in pigs (Joint FAO/WHO Expert Committee on Food Additives [JECFA], 1995).

Studies have demonstrated that a significant fraction of OTA was present in the shell of cocoa beans that is removed during cocoa processing (Bonvehi, 2004; Amezqueta et al., 2005). This action would result in a cutting down of about 70\% in OTA levels (Amezqueta et al., 2005; Gilmour \& Lindblom, 2005; Dembele et al., 2007). However, it is just not possible to completely eliminate the shell of cocoa products. Codex Alimentarius allows about $2 \%$ of shells in shelled beans also called nibs (Codex Alimentarius [CA], 2001). OTA could contaminate products of nibs and threaten consumers' health.

The lack of data pertaining to OTA intakes from cocoa products makes it difficult to assess the health risks to consumers, thereby crippling governmental and/or international agencies regulatory safety measures. This study is an attempt to determining the contamination level of OTA in cocoa beans and estimating the intake in the Ivorian adult.

\section{Material and Methods}

\subsection{Sampling}

The plant material used consisted of cocoa beans collected from December 2005 to July 2009 at ports and production areas. 1895 samples were collected according to regulations 401/2006/CE (Commission Européenne [CE], 2006) (Table 1). Sampling was carried out according to a spatial coverage of all the Ivorian production areas of cocoa beans. On the basis of data from the Ivorian Coffee and Cocoa stock exchange (Bourse du Café-Cacao [BCC], 2009); samples were collected according to the amount of production of the area. Based upon the standards of quality of the Ivoirian's Exchange coffee and cocoa board and the European Commission on the presence of OTA (CA, 2007; BCC, 2009) (Table 2), these samples were divided into batches depending on merchantability criteria and OTA levels: total beans, marketable beans, nonmarketable beans. Inside every batch, OTA was estimated for shells, shelled beans and chocolate. On shelled beans and chocolate, OTA was theoretically calculated from different batches of whole beans and literature data. These data indicate that OTA is lost 70\% after shelling beans (Amezqueta et al., 2005; Gilmour \& Lindblom, 2005; Dembele, et al., 2007) and dark chocolate, sweet chocolate and milk chocolate contain respectively $35 \%, 30 \%$ and $25 \%$ cocoa mass (CA, 2003) (Table 2).

Table 1. Number of samples per ports, production areas and campaigns

\begin{tabular}{ccccc}
\hline & \multicolumn{3}{c}{ Cocoa bean crops } & \multirow{2}{*}{ Total } \\
\cline { 2 - 4 } & $2005-2006$ & $2007-2008$ & $2008-2009$ & \\
\hline Abidjan port & 150 & 120 & 97 & 367 \\
San pedro port & 150 & 150 & 150 & 450 \\
Production areas & - & 567 & 511 & 1078 \\
\hline
\end{tabular}

Table 2. Criteria of exportable beans and OTA distribution

\begin{tabular}{|c|c|c|c|}
\hline \multicolumn{4}{|c|}{ Criteria of Exportable Beans } \\
\hline \multicolumn{4}{|c|}{ Marketable beans } \\
\hline Moisture & \multicolumn{3}{|c|}{$\leq 8 \%$} \\
\hline Graining & \multicolumn{3}{|c|}{$\leq 105$ fèves pour $100 \mathrm{~g}$} \\
\hline Grade & \multicolumn{3}{|c|}{ Grade 1 et 2} \\
\hline Concentration of OTA & \multicolumn{3}{|c|}{$\leq 2 \mu \mathrm{g} / \mathrm{kg}$} \\
\hline \multicolumn{4}{|c|}{ Distribution of OTA In Beans } \\
\hline & Whole bean & Shelled bean & Shells \\
\hline Occurrence of OTA $(\%)$ & $100 \%$ & $30 \%$ & $70 \%$ \\
\hline \multicolumn{4}{|c|}{ Proportion of Cocoa Mass in Chocolate } \\
\hline & 3lack chocola & Sweet chocolate & Milk chocolate \\
\hline Cocoa mass (\%) & 35 & 30 & 25 \\
\hline
\end{tabular}

Sources: BCC, 2009; CA, 2007; Amezqueta et al., 2005; Gilmour \& Lindblom, 2005; Dembele et al., 2007; CA, 2003. 


\subsection{Determination of Ochratoxin A}

\subsubsection{Extraction of OTA}

The entire sample was crushed in a hammer mill to obtain a homogeneous fine grind. In a Nalgene jar containing $15 \mathrm{~g}$ of homogenate, $150 \mathrm{~mL}$ of aqueous methanol-bicarbonate $1 \%(\mathrm{~m} / \mathrm{v}, 50: 50)$ were added. The mixture was homogenized by Ultra-Turax for 3 minutes and then centrifuged at $5000 \mathrm{rpm}$ for $5 \mathrm{~min}$ at $4{ }^{\circ} \mathrm{C}$. The supernatant was filtered through filter paper into tubes of $25 \mathrm{~mL}$. To $11 \mathrm{~mL}$ of filtrate were added $11 \mathrm{ml}$ of saline phosphate buffered (PBS) at $\mathrm{pH}$ 7.3. Immunoaffinity columns brand Ochraprep and R-Biopharm were conditioned with 10 $\mathrm{mL}$ of PBS. Purification of $20 \mathrm{ml}$ of the mixture was made on immunoaffinity columns and OTA extraction was performed using two volumes of $1.5 \mathrm{~mL}$ of PBS at a flow rate of $5 \mathrm{~mL} /$ minute. The resulting sample was packed in a chromatographic tube and the analysis of OTA was made by HPLC in compliance with the European community regulation (CE 401/2006).

\subsubsection{Apparatus}

A liquid chromatograph HPLC brand Shimadzu coupled to a fluorescence detector was used and the operating conditions are described in Table 3.

Table 3. HPLC analytical conditions

\begin{tabular}{ll}
\hline Precolumn & Shim-pack GVP-ODS $10 \times 4.6 \mathrm{~mm}$ \\
\hline Column & Shim-pack GVP-ODS $250 \mathrm{~mm} \times 4.6 \mathrm{~mm}$ \\
Detector & Flurescence, $\lambda$ excitation: $330 \mathrm{~nm}, \lambda$ emission: $460 \mathrm{~nm}$ \\
Mobile phase & Acetonitrile/Water/Acetic acid (99/99/2) \\
Injected volume & $100 \mu \mathrm{L}$ \\
Flow rate & $1 \mathrm{~mL} /$ minute \\
Column temperature & $40^{\circ} \mathrm{C}$ \\
Rinsing solvent & Acetonitrile \\
Analysis duration & 12 minutes \\
\hline
\end{tabular}

\subsection{Measuring the Concentration of Ochratoxin A in Chocolate}

In 2003, the Codex Alimentarius has set the composition of cocoa mass in different chocolates. Dark chocolate, sweet chocolate and milk chocolate must contain respectively $35 \%, 30 \%$ and $25 \%$ cocoa mass obtained from shelled or unshelled beans (CA, 2003). These data were used to roughly estimate OTA levels in shelled or unshelled based chocolates.

\subsection{Estimated Intake of Ochratoxin A}

OTA intakes were assessed using data obtained from the analysis and the estimated Ivorian adult daily consumptions of cocoa beans and chocolate set by the International Cocoa Organization. According to this institution, the daily consumption of cocoa and chocolate are respectively $1.345 \mathrm{~g}$ per capita/day and $0.384 \mathrm{~g}$ per capita/day (ICCO, 2006). This intake was also estimated for the maximum residue limit of OTA set at $2 \mu \mathrm{g} / \mathrm{kg}$ of cocoa bean (CA, 2007). The estimated intakes were expressed as a proportion of the Tolerable Daily Intake (TDI) set at $5 \mathrm{ng} / \mathrm{kg}$ body weight/day by the Superior Council for Public Hygiene of France and the Scientific Committee on Food (CSHPF, 1999; SCF, 1998). The intake of OTA was calculated using formula 1 (Word Health Organization [WHO], 2003):

$$
\text { OTA intake }=\mathrm{T}_{\text {OTA }} \times \mathrm{C}
$$

$\mathrm{T}_{\text {ОТА }}$ : OTA concentration found in cocoa $(\mu \mathrm{g} / \mathrm{kg}$ of product)

$\mathrm{C}$ : daily consumption of cocoa or chocolate of the individual $70 \mathrm{~kg}$ adult (g/day)

\subsection{Statistical Analysis}

The mean concentrations of OTA were calculated with their standard deviations. The corresponding proportions of the Tolerable Daily Intake were computed. The homogeneity of the mean concentrations of OTA was assessed by an analysis of variance through the F-test, using SPSS 12 at 5\% risk.

\section{Results}

\subsection{Concentrations of OTA in Cocoa Beans and Chocolate}

Mean levels of OTA found in samples of beans of different qualities were respectively $0.64 \pm 0.53 \mu \mathrm{g} / \mathrm{kg}$ and 
$1.90 \pm 1.87 \mu \mathrm{g} / \mathrm{kg}$ for exportable and non-exportable beans with $1.40 \pm 1.32 \mu \mathrm{g} / \mathrm{kg}$ for all the beans (Table 4). The homogeneity of OTA concentrations by analysis of variance (quality of beans) through the F-test revealed a significant difference at 5\% risk (Table 4). Exportable beans had the lowest contamination level. $20 \%$ of the samples had OTA content above the maximum concentration of $2 \mu \mathrm{g} / \mathrm{kg}$ proposed by the regulations of the European Communities (CA, 2007) while 33\% of the non-exportable were beyond that limit. The proportions of samples that are below the method detection limit $(0.05 \mu \mathrm{g} / \mathrm{kg}$ ) were as follows: $18 \%$ (exportable beans), $10 \%$ (non-exportable) and 13\% (all beans combined). Regarding the types of beans (shelled or not), the concentrations of OTA ranged from $0.19 \pm 0.16 \mu \mathrm{g} / \mathrm{kg}$ for shelled beans and $1.90 \pm 1.87 \mu \mathrm{g} / \mathrm{kg}$ for unshelled beans (Table 5). The levels of OTA found in shells ranged from $0.45 \pm 0.37 \mu \mathrm{g} / \mathrm{kg}$ for the shells from exportable beans and $1.33 \pm 1.31 \mu \mathrm{g} / \mathrm{kg}$ for the shells from non-exportable beans. The homogeneity of OTA concentrations by analysis of variance (type of bean), through the F-test revealed a significant difference at $5 \%$ risk (Table 5).

Table 4. OTA levels in different cocoa beans batches (Concentration in $\mu \mathrm{g} / \mathrm{kg}$ ).

\begin{tabular}{lllll}
\hline \multirow{2}{*}{ Mean } & [Min-Max] & \multicolumn{2}{c}{ Batch percentage } \\
$<$ LD & $>$ MRL \\
\hline Total beans & $1.40 \pm 1.32 \mathrm{~b}$ & $0.05-14.75$ & $13 \%$ & $20 \%$ \\
Exportable beans & $0.64 \pm 0.53 \mathrm{c}$ & $0.05-2.00$ & $18 \%$ & $0 \%$ \\
Non-exportable beans & $1.90 \pm 1.87 \mathrm{a}$ & $0.05-14.75$ & $10 \%$ & $33 \%$ \\
\hline column with the same letter are not significantly different at 5\% risk.
\end{tabular}

Values in a column with the same letter are not significantly different at $5 \%$ risk.

LD: limit of detection $(0.05 \mu \mathrm{g} / \mathrm{kg})$.

MRL: maximal residues limit $(2 \mu \mathrm{g} / \mathrm{kg})$.

Table 5. OTA level in different parts of beans (Concentration in $\mu \mathrm{g} / \mathrm{kg}$ )

\begin{tabular}{llll}
\hline & Unshelled beans & Shelled beans (Nibs) & Shells \\
\hline Total beans & $1.40 \pm 1.32 \mathrm{~b}$ & $0.42 \pm 0.40 \mathrm{~b}$ & $0.98 \pm 0.96 \mathrm{~b}$ \\
Exportable beans & $0.64 \pm 0.53 \mathrm{c}$ & $0.19 \pm 0.16 \mathrm{c}$ & $0.45 \pm 0.37 \mathrm{c}$ \\
Non-exportable beans & $1.90 \pm 1.87 \mathrm{a}$ & $0.57 \pm 0.55 \mathrm{a}$ & $1.33 \pm 1.31 \mathrm{a}$ \\
\hline
\end{tabular}

Values in a column with the same letter are not significantly different at $5 \%$ risk.

The concentrations of OTA in chocolate made from unshelled beans ranged from $0.16 \pm 0.13 \mu \mathrm{g} / \mathrm{kg}$ for milk chocolate and $0.66 \pm 0.65 \mu \mathrm{g} / \mathrm{kg}$ for dark chocolate. As for chocolate made from shelled beans, OTA levels were between $0.048 \pm 0.040 \mu \mathrm{g} / \mathrm{kg}$ for milk chocolate and $0.067 \pm 0.056 \mu \mathrm{g} / \mathrm{kg}$ for dark chocolate (Table 6). Chocolates obtained with all beans had concentrations of OTA levels ranging from $0.11 \pm 0.10 \mu \mathrm{g} / \mathrm{kg}$ for milk chocolate and $0.15 \pm 0.14 \mu \mathrm{g} / \mathrm{kg}$ for dark chocolate.

Table 6. Concentration of OTA in different types of chocolates (Concentration in $\mu \mathrm{g} / \mathrm{kg}$ )

\begin{tabular}{llll}
\hline Unshelled beans & & & \\
Designation & Total beans & Exportable beans & Non-exportable beans \\
\hline Dark chocolate & $0.49 \pm 0.47$ & $0.22 \pm 0.19$ & $0.66 \pm 0.65$ \\
Sweet chocolate & $0.42 \pm 0.41$ & $0.19 \pm 0.16$ & $0.57 \pm 0.56$ \\
Milk chocolate & $0.35 \pm 0.34$ & $0.16 \pm 0.13$ & $0.48 \pm 0.47$ \\
Shelled beans & & & \\
Designation & Total beans & Exportable beans & Non-exportable beans \\
Dark chocolate & $0.15 \pm 0.14$ & $0.067 \pm 0.056$ & $0.20 \pm 0.19$ \\
Sweet chocolate & $0.13 \pm 0.12$ & $0.057 \pm 0.048$ & $0.17 \pm 0.16$ \\
Milk chocolate & $0.11 \pm 0.10$ & $0.048 \pm 0.040$ & $0.14 \pm 0.13$ \\
\hline
\end{tabular}

\subsection{OTA Intakes from Cocoa Beans and Chocolate}

OTA intakes estimated from the consumption of unshelled cocoa beans ranged from $12.3 \pm 10 \mathrm{pg} / \mathrm{kg}$ body weight/day for exportable beans to $36.5 \pm 34.0 \mathrm{pg} / \mathrm{kg}$ body weight/day for non-exportable beans (Table 7). With regard to the shelled beans, these intakes ranged from $3.70 \pm 3.00 \mathrm{pg} / \mathrm{kg}$ body weight/day for exportable beans to 
$11.0 \pm 10.0 \mathrm{pg} / \mathrm{kg}$ body weight/day for non-exportable beans (Table 7). As a result, a $70 \mathrm{~kg}$ adult Ivorian adult who consumes daily $1.345 \mathrm{~g}$ cocoa ingests between $259 \mathrm{pg}$ /day and $2555 \mathrm{pg}$ /day of ochratoxin A that is $0.07 \%$ to $0.73 \%$ of TDI ( $5 \mathrm{ng} / \mathrm{kg}$ body weight/day) set by the Scientific Committee on Food (CSF, 1998). OTA intakes are also lower (10-95\%) than the dose of OTA calculated from the maximum concentration of OTA $(2 \mu \mathrm{g} / \mathrm{kg})$ proposed by the European Commission (CA, 2007) in cocoa (Table 9).

Table 7. OTA intakes estimated from the consumption of cocoa beans from Ivorian adult (Intake $\mathrm{pg} / \mathrm{kg}$ body weight/day)

\begin{tabular}{llll}
\hline & Total beans & Exportable beans & Non-exportable beans \\
\hline Unshelled beans & $26.9 \pm 25.1$ & $12.3 \pm 10.0$ & $36.5 \pm 34.0$ \\
Shelled beans (Nibs) & $8.10 \pm 7.11$ & $3.70 \pm 3.00$ & $11.0 \pm 10.0$ \\
Estimated intake to MRL (AELMR 1$)$ & 38 & & \\
Reference value SCF & 5000 & & \\
\hline
\end{tabular}

$\mathrm{AELMR}_{1}$ : estimated intake for a maximum residue level of OTA in exported beans.

SCF: Tolerable daily Intake recommended by the scientific committee on food.

OTA intakes from different chocolates (dark, sweet and milk) were also compared with the TDI set by the CSF and that calculated from the maximum concentration of OTA in cocoa beans proposed by the European Commission. For chocolate made from unshelled beans, the calculated values ranged from $0.90 \pm 0.70 \mathrm{pg} / \mathrm{kg}$ body weight/day for exportable beans and $3.60 \pm 3.44 \mathrm{pg} / \mathrm{kg}$ body weight/day for non-exportable beans (Table 8 ). Chocolate made from shelled beans were associated with intakes comprised between $0.3 \pm 0.20 \mathrm{pg} / \mathrm{kg}$ body weight/day for exportable beans and $1.10 \pm 0.91 \mathrm{pg} / \mathrm{kg}$ body weight/day for non-exportable beans (Table 8 ). According to the Codex Alimentarius (2003), dark chocolate contains the maximum of cocoa mass (35\%) and milk chocolate the least (25\%). The estimated intakes in the Ivorian adult consumers of chocolate do not exceed $0.073 \%$ of the TDI for dark chocolate made from unshelled non-exportable beans and $0.022 \%$ for that chocolate made from shelled non-exportable beans (Table 9). The chocolate made from cocoa beans containing $2 \mu \mathrm{g} / \mathrm{kg}$ of OTA would provide $0.77 \%$ of the TDI set by the CSF.

Table 8. OTA intakes estimated from the consumption of chocolate in the Ivorian adult (Intake $\mathrm{pg} / \mathrm{kg}$ body weight/day)

\begin{tabular}{cccc}
\hline \multicolumn{5}{c}{ Unshelled beans } \\
\hline Désignation & Total beans & Exportable beans & Non-exportable beans \\
Dark chocolate & $2.70 \pm 2.37$ & $1.20 \pm 1.10$ & $3.60 \pm 3.44$ \\
Sweet chocolate & $2.30 \pm 2.32$ & $1.10 \pm 0.90$ & $3.10 \pm 2.38$ \\
Milk chocolate & $1.90 \pm 1.26$ & $0.90 \pm 0.70$ & $2.60 \pm 2.32$ \\
& Shelled beans & \\
Désignation & Total beans & Exportable beans & Non-exportable beans \\
Dark chocolate & $0.80 \pm 0.71$ & $0.40 \pm 0.30$ & $1.10 \pm 0.91$ \\
Sweet chocolate & $0.70 \pm 0.61$ & $0.30 \pm 0.23$ & $0.90 \pm 0.81$ \\
Milk chocolate & $0.60 \pm 0.58$ & $0.30 \pm 0.20$ & $0.80 \pm 0.69$ \\
& Reference intake & 11 & \\
Estimated intake to MRL (AELMR $)$ & \multicolumn{4}{c}{5000} & \\
Reference value SCF & & &
\end{tabular}

$\mathrm{AELMR}_{2}$ : estimated intake for a maximum residue level of OTA in exported beans.

SCF: Tolerable daily Intake recommended by the Scientific committee on food. 
Table 9. Proportion of estimated intakes for cocoa products in comparison with the reference values (\%)

\begin{tabular}{|c|c|c|c|c|c|c|}
\hline \multicolumn{7}{|c|}{ QUALITY OF EXPORTABLE BEANS } \\
\hline \multirow[b]{2}{*}{ Designation } & \multicolumn{2}{|c|}{ Total beans } & \multicolumn{2}{|c|}{ Exportable beans } & \multicolumn{2}{|c|}{ Non-exportable beans } \\
\hline & $\mathrm{AE} / \mathrm{AELMR}_{1}$ & $\mathrm{AE} / \mathrm{SCF}$ & $\mathrm{AE} / \mathrm{AELMR}_{1}$ & $\mathrm{AE} / \mathrm{SCF}$ & 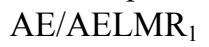 & $\mathrm{AE} / \mathrm{SCF}$ \\
\hline Unshelled beans & 70 & 0.54 & 32 & 0.25 & 95 & 0.73 \\
\hline Shelled beans & 21 & 0.16 & 10 & 0.07 & 30 & 0.22 \\
\hline \multicolumn{7}{|c|}{ TYPE OF CHOCOLATE } \\
\hline \multirow{2}{*}{ Designation } & \multicolumn{2}{|c|}{ Total beans } & \multicolumn{2}{|c|}{ Exportable beans } & \multicolumn{2}{|c|}{ Non-exportable beans } \\
\hline & ${\mathrm{AE} / \mathrm{AELMR}_{2}}$ & $\mathrm{AE} / \mathrm{SCF}$ & 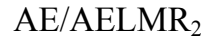 & $\mathrm{AE} / \mathrm{SCF}$ & ${\mathrm{AE} / \mathrm{AELMR}_{2}}$ & $\mathrm{AE} / \mathrm{SCF}$ \\
\hline Dark chocolate & 25 & 0.054 & 11 & 0.025 & 33 & 0.073 \\
\hline Sweet chocolate & 21 & 0.046 & 10 & 0.021 & 29 & 0.062 \\
\hline Milk chocolate & 18 & 0.038 & 8 & 0.018 & 24 & 0.052 \\
\hline \multicolumn{7}{|c|}{ Shelled beans } \\
\hline \multirow{2}{*}{ Designation } & \multicolumn{2}{|c|}{ Total beans } & \multicolumn{2}{|c|}{ Exportable beans } & \multicolumn{2}{|c|}{ Non-exportable beans } \\
\hline & ${\mathrm{AE} / \mathrm{AELMR}_{2}}$ & $\mathrm{AE} / \mathrm{SCF}$ & 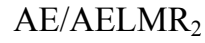 & $\mathrm{AE} / \mathrm{SCF}$ & 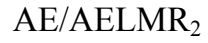 & $\mathrm{AE} / \mathrm{SCF}$ \\
\hline Dark chocolate & 7 & 0.016 & 3 & 0.007 & 10 & 0.022 \\
\hline Sweet chocolate & 6 & 0.014 & 3 & 0.006 & 9 & 0.019 \\
\hline Milk chocolate & 5 & 0.012 & 2 & 0.005 & 7 & 0.016 \\
\hline $\mathrm{AELMR}_{1} / \mathrm{SCF}$ & & & 0.77 & & & \\
\hline $\mathrm{AELMR}_{2} / \mathrm{SCF}$ & & & 0.22 & & & \\
\hline
\end{tabular}

$\mathrm{AE}$ : estimated intake for various cocoa products

$\mathrm{AELMR}_{1}$ : estimated intake for a maximum residue level of OTA in exported beans.

$\mathrm{AELMR}_{2}$ : estimated intake for a maximum residue level of OTA in chocolates.

SCF: Tolerable Daily Intake recommended by the scientific committee on food.

\section{Discussion}

The average concentrations of OTA found in cocoa beans of different grade (exportable, non-exportable and total) are below the maximum residue of OTA $(2 \mu \mathrm{g} / \mathrm{kg})$, proposed by the regulation of the European Communities (CA, 2007). This low rate of OTA indicates the application of good production practices and marketing of cocoa beans? However, $20 \%$ of the Ivorian production goes beyond this set value. These results unquestionably point out the fact that OTA contamination of Ivorian cocoa remains a huge concern due not only to health issues but also to economic reasons. As a matter of fact, it could imply a financial loss of 402.77 millions dollars for a market value of 1.68 dollars per kilogram of cacao (BCC, 2006). Efforts should be made by authorities to reduce to a minimum rejection percentage. This requires the control of entire production chain of planter to exporter. Our results seem corroborating those of several previous studies that focused on shelled beans (Amezqueta, et al. 2005; Gilmour \& Lindblom, 2005; Dembele, et al., 2007). Indeed, the removal of shells leads to a reduction of about $30 \%$ of the maximum residue limit (MRL).

From the average concentrations of OTA found in beans of various qualities, OTA intakes in the Ivorian adult remain well below the Tolerable Daily Intake ( $5 \mathrm{ng} / \mathrm{kg}$ body weight/day) set by the Scientific Committee on Food (SCF, 1998). This value is approximately three times lower than the TDI (14 ng/kg body weight/day) set by the Joint FAO/WHO Expert Committee on Food Additives and Contaminants (JECFA, 1995). The amounts of OTA from the consumption of chocolate are even lower. Ivorian cocoa and derivatives are responsible for a small proportion of the total contamination of food bolus in OTA. However, taking into account the carcinogenic, mutagenic and teratogenic effects of ochratoxin A, the presence of this compound, even at very low doses could be a hazard to the consumer. In addition, amounts of OTA found in other foods (grains, dried tubers and legumes) can add up to a higher intake, thereby to increased health concerns. The estimated intake for the French population by National Institute on Agronomic Research is $2200 \mathrm{Pg} / \mathrm{kg}$ body weight/day for adults. The vector contributing most exposure for this population group is represented by $70 \%$ of cereals and cereal products (breads, crackers, breakfast cereals, pasta, rice and semolina) (National Institute on Agronomic Research [INRA], 2004).

\section{Conclusion}

This study determined the level of OTA in cocoa beans of different qualities and three types of chocolate in order 
to estimate the amounts of the compound ingested by the Ivorian adult. It revealed that OTA contamination was still low and on average far below the maximum limit proposed by the European Commission. The computed intakes, regardless of the type of beans and chocolate, are also below the Tolerable Daily Intake set by the Scientific Committee on Food. However, in view of the toxicity of OTA, it is imperative to foster best practices of harvesting, pod breaking, drying and storage of the beans for the total elimination of OTA from Ivorian cocoa beans.

\section{References}

Amezqueta, S., Gonzalez-Penas, E., Murillo, M., \& Lopez de Cerfin, A. (2005). Occurrence of ochratoxine A in cocoa beans: effect of shelling. Food Additives and Contam, 22, 590-595. http://dx.doi.org/10.1080/02652030500130160

Bourse du Café et du Cacao. (2006). Rapport technique : analyse de la commercialisation du café et du cacao campagne 2005-2006. Période Octobre 2005- Mars 2006. Avril 2006, p.7.

Bourse du Café et du Cacao. (2009). Qualité du cacao. www.bcc.ci/normes-cacao.asp. Visité le 20/07/2009.

Bonvehi, S. J. (2004). Occurrence of ochratoxin A in cocoa products and chocolate. J. Agric. Food Chem, 52, 6347-6352. http://dx.doi.org/10.1021/jf040153w

Boorman, G. A., Hong, H. L., Dieter, M. P., Hayes, H. T., Pohland, A. E., Stack, M., \& Luster, M. I. (1984). Myelotoxicity and macrophage alteration in mice exposed to ochratoxin A.- Toxicol. Appl. Pharmacol., 72, 304-312. http://dx.doi.org/10.1016/0192-0561(84)90045-6

Burdaspal, P. A., \& Legarda, T. M. (2003). Ochratoxin A in samples of different types of chocolate and cacao powder, marketed in Spain and fifteen foreign countries. Alimentaria, 347, 143-153.

Christine Vinkx. (2007). Personnal communication (Codex electronic Working Group on OTA in Cocoa).

Castegnaro, M. (1999). Risques cancérogènes dans : Mycotoxines : Evaluation et gestion du risque, chapitre 5, Lavoisier, Tec \& Doc, Paris, 121-140.

Castegnaro, M., Mohr, U., Pfohl-leszkowicz, A., Esteve, J., Steinmann, J., Tilmann, T., ... Bartsch, H. (1998). Sex and Strain specific induction of renal tumours by ochratoxin A in rats correlates with DNA adduction. $\begin{array}{lllll}\text { Int. } & \mathrm{J} . & \text { Cancer, } & 77, & 70-75 .\end{array}$ http://dx.doi.org/10.1002/(SICI)1098-2744(199810)23:2<76::AID-MC4>3.3.CO;2-2

Codex Alimentarius. (2001). CODEX STAN 141-1883, Rev. 1-2001.

Codex Alimentarius. (2003). CODEX STAN 87-1981, Rév. 1-2003.

Codex Alimentarius. (2007). Programme mixte FAO/OMS sur les normes alimentaires, comité du codex sur les contaminants dans les aliments. Document de travail sur l'ochratoxine A dans le cacao. CX/CF 07/1/19, Beijing, p.15.

Commission Européenne. (2006). Règlement (CE) No 401/2006 de la commission du 23 février 2006 portant fixation des modes de prélèvement d'échantillons et des méthodes d'analyse pour le contrôle officiel des teneurs en mycotoxines des denrées alimentaires. Journal Officiel de l'Union Européenne L70/12.

Conseil Supérieur de l'Hygiène Publique de France. (1999). Les mycotoxines dans l'alimentation: évaluation et gestion du risque, éds TEC \& DOC, 1999.

Dembélé, A., Gérard, F., Manda, P., \& Nemlin, J. G. (2007). Résultats des études de recherche du devis programme OTA No. DP/IVC/2005/16: Contamination du café et du cacao par l'ochratoxine A (OTA) en Cote d'Ivoire. Rapport de synthèse 2007. Ministère de l'Agriculture, Direction Générale des Productions et de la Diversification Agricoles, République de Cote d'Ivoire.

Dembélé, A., Coulibaly, A., Traoré, S. K., Mamadou, K., Silue, N., \& Abba, T. A. (2009). Détermination du niveau de contamination de l'ochratoxine A (OTA) dans les fèves de cacao à l'exportation. TROPICULTURA, 27( 1), 26-30.

Dwidedi, P., \& Burns, R. B. (1984). Effect of ochratoxin A on immunoglobulins in broiler chicks.- Res. In Vet. Sci., 36, 117-121.

Gilmour, M., \& Lindblom, M. (2005). Management of ochratoxin A in the cocoa supply chain. MYCOGLOBE Conference: Reducing Impact of Mycotoxins in Tropical Agriculture with Emphasis on Health and Trade in Africa. Accra, Ghana, 13-16 September 2005.

International Agency for Research on Cancer. (1993). Ochratoxin A. In: IARC monographs on the evaluation of 
carcinogenic risks to humans: some naturally occurring substances; food items and constituents, heterocyclic aromatic amines and mycotoxins, vol. 56, Lyon, pp. 489-521.

International Cocoa Organization. (2006). Assessment of the movement of global supply and demand, 2006, p. 32.

International Cocoa Organization. (2007). Production of Cocoa Beans. Quarterly Bulletin of Cocoa Statistics. http://www.icco.org/statistics/production.aspx (posted 22 October 2007).

Joint FAO/WHO Expert Committee on Food Additives. (1995). Evaluation of certain food additives and contaminants. $44^{\text {éme }}$ report. WHO Technical Report Series No. 859, p35-36.

Maaroufi, A., Achour, A., Zakhama, A., Ellouz, F., El May, M., Creppy, E. E., \& Bacha, H. (1996). Human nephropathy related to ochratoxin A in Tunisia. Journal of Toxicology: Toxin Reviews, 15, 223-237. http://dx.doi.org/10.1016/0041-0101(96)00008-6

Matsuoka, T. (2006). OTA contamination in retail chocolate in Japan in 2005. Standards and Evaluation Division, Department of Food Safety, Ministry of Health, Labour \& Welfare, Tokyo, Japan. (Personal Communication).

Miraglia, M., \& Brera, C. (2002). Assessment of dietary intake of ochratoxin A by the population of EU member states, Reports on tasks for scientific cooperation, task 3.2.7., 69-86. Publisher: SCOOP Directorate-General Health and Consumer Protection.

Moré, J., \& Galtier, P. (1974). Toxicité de l'ochratoxine A. I. Effet embryotoxique et tératogène chez le rat.- Ann. Rech. Vet., 5, 167-178.

National Institute on Agronomic Research. (2004). Etude de l'alimentation totale française. Mycotoxines, minéraux et éléments traces. Rapport INRA/DGAL. Coordinateur Jean-Charles Leblanc. p. 72.

Organisation Mondiale de la Santé. (2003). Régime alimentaire, nutrition et prévention des maladies chroniques, Rapport d'une consultation OMS/FAO d'experts, Genève, OMS, Série de rapport technique, nº 916, p.189.

Petrova-Bocharova, T., Chernozemsky, I. N., \& Castegnaro, M. (1988). Ochratoxin A in human blood in relation to Balkan endemic nephropathy and urinary system tumours in Bulgaria. Food additives and Contaminants, 5, 299-301. http://dx.doi.org/10.1080/02652038809373707

Scientific Committee on Food. (1998). Opinion of the Scientific Committee on Food on Ochratoxin A (expressed on 17 September 1998).

Tafuri, A., Ferracane, R., \& Ritieni, A. (2004). Ochratoxin A in Italian marketed cocoa products. Food Chem, 88 487-494. http://dx.doi.org/10.1016/j.foodchem.2004.01.061

Waffa, E. W., Yahya, R. S., Sobh, M. A., Eraky, I., El Baz, M., El Gayar, ... Creppy, E. E. (1998). Human ochratoxicosis and nephropathy in Egypt: a preliminary study. Human Experimental Toxicology, 17, 124-129. http://dx.doi.org/10.1191/096032798678908369 